\title{
MICROLOAN CONSTRAINTS IMPOSED BY COMMERCIAL BANK BRANCHES IN THE SOUTH AND WEST SULAWESI PROVINCE
}

\author{
Andi Aswan \\ Maastricht School of Management
}

\begin{abstract}
This study is aimed to identify possible constraints to which loan officers assigned in state and regional development bank branches are unwillingness to supply loan to micro businesses, as well as to how an integrated constraints is built to affect loan officers' judgment and decision to grant loan to those micro customers. The sampling covered 122 loan officers assigned in four state banks and five different regional banks. All of these are based within South and West Sulawesi Province in Indonesia. On the basis of the statistical analysis result using LISREL Program 9.2, The three paths indicated a positive and significant relationship with a different coefficient parameter for each. The external-specific condition affects positively and significantly the internal-specific condition, and the external-specific condition also affects positively and significantly the loan officer judgment(s) and decision(s), the internal-specific condition affects positively and significantly the loan officer judgment(s) and decision(s) as well.
\end{abstract}

Keywords: Loan Officer, Micro Business, Commercial Banks, Microloan.

\section{INTRODUCTION}

This study is intended to assist micro business to obtain credit access from commercial banks, particularly in the eastern part of Indonesia. This motivation arises because the amount of productive loan supply for micro businesses by commercial banks is still low (Rosengard \& Praseyantoko, 2011and Machmud \& Huda, 2011). Micro loans granted are mostly in the form of consumption

*Corresponding author's email: Aswan@msm.nl ISSN: 2549-3221 (Print) 2549-323X (Online) DOI: 10.26487/hebr.v1i1.1189 
credits (Tambunan, 2015 and Research Development Agency of North Sumatera Province, 2011). In addition, micro businesses are treated very potential by many lenders, such as cooperatives, rural banks, informal lenders and others, since they are able to make loan supply with a good quality to this customer even with high interest. The low loan supply for micro businesses performed by commercial banks are not unique to Indonesia, though, have occurred in both developed countries and developing countries (e.q. Martin, 2010; Skiba and Tobacman, 2009; Montiel et al., 1993; Wardoyo and Probowo, 2005)

With respect to the micro credit environment by commercial banks in Indonesia, there is an extensive literature that ever discusses it, but they have differently focused features. Among the scholar, for example, Patten and Johnston (2001), Sastrosiwito \& Suzuki (2012) focused only on economic condition. Winarni (2006) and Sutrisno (2006), using the descriptive qualitative method, discussed constraints imposed by micro-enterprises like creditterms and internal bank branches' policies such as administrations, application procedures and etc. Still related to internal bank, Nuswantara (2012) and Meydianawathi (2007) came up with a research centered on saving, profitability, capital adequacy, and non-performing loan to testing the ability of commercial banks to provide investment and working credit to SMEs in Indonesia. With a different focus, Angraini \& Nasution (2013) discussed that characteristic item hampering micro business to have a possible access from commercial banks.

This study to wide extent provides differently focused variables of the external and internal factors. Two external features, the study discusses the regional competition condition, economic condition, market-size condition, and socioeconomic condition. With the exception of the regional economic condition, these external features are absent in Indonesia, but they have ever been discussed in some countries in the world. For example, in England by Armstrong (2013), in Belgium and US by Degryse and Ongena (2007), and in the US by Berger et al. (2007) and Northcott (2004). Similar to the external features, the internal features to a wide extent are also unique in the national level of Indonesia. A few researchers have discussed loan rate and fund availability, but to fund availability, they provide a different measurement using secondary data of savings(Nuswantara, 2012; and Sudirman, 2003). Further, we did not find any study that ever takes into account loan plan and managerial decision. As to know, these indicators could affect loan supply decision to micro customers in bank branch level (Hampel and Simonson, 1999; Liberti and Atif, 2009; and Berger and Udell, 2002).

Besides to the external and internal factors, the study also takes into account loan officer features. To the best of the knowledge, these features have not yet been ever discussed so far in in the South and West Sulawesi Province. At the national level, microloan studies are mostly absent with discussion of loan officer roles. In fact, loan officers play a key point surrounding loan decisions as they are involved, to a large extent, to screen, to evaluate and to decide as well as to monitor whether an application is eligible or not to be financed (Hemple and Simonso, 1999; Manove et. al. 2001; and Stein, 2002 cited in Benvenuti et. al., 2010). In bank branch level, credit officers are widely dominant to affect loan supply decision (Indra, 2016; Shahban et al., 2014; and Siregar, 2004).

To microloan environment, there were only a few studies that ever discuss it, but in different geographical areas 
in Indonesia like in Java or Sumatera Island (e.g. Anggraini \& Nasution, 2013). The different area could cause different ways of attracting customers and it also could provide a different risk perspective perceived by loan officers. Accordingly, this is likely to affect loan screening made by loan officers (Tambunan, 2015).

Aside from the loan officer's perspective commercial bank branches will be earning more benefit when dealing with micro business customers. In terms of numbers, in accordance with the data recorded by the Ministry of Cooperatives and Small and Medium Enterprises of the Republic of Indonesia by 2013, micro enterprises in Indonesia reached 57.19 million or $99.99 \%$ of the business operating in Indonesia. The employment absorption from the businesses reached 104.62 million or approximately $88.90 \%$ of the workforce. To business stability and continuity, micro businesses mostly operate to meet the needs of the local people so that they are not vulnerable to economy shock globally, nationally, and regionally (Sutrisno, 2006).

Besides, micro business customers are potential for investment as in many they are able to perform loan repayment with high interest. It is the fact that many micro-businesses are likely to deal with cooperatives, rural bank and informal lenders that could, to many extents, provide high interest compared with interest offered by commercial banks. This impact is absolutely true since those lending institutions are a lack of funds to support their operational activities so that they often need loans from commercial banks to support their lending abilities.

Considering the bright prospects of distributing loans to micro business, the study is aimed to identify factors contributing to affect the decision made by loan officers to approve the loan to micro businesses. The study, therefore, focuses digging on the internal and external determinants that could contribute to making the loan officers assigned to micro business are reluctant or afraid to make loan supply decision to micro business in the province of the South Sulawesi. Also, the study will analyse how these two factors composed into an integrated model to affect loan supply decision to micro businesses?

\section{KONSEPTUAL FRAMEWORK}

Bank has several decisional options in investing its funds (Riyadi, 2006). The decision made could affect other investment opportunities. When a bank prefers to invest its funds more into certain preference portfolio, except loan portfolio, the amount offund allocated ina loan portfolio would certainly be affected and show a decrease (Pratama, 2010; and Obamunyi, 2009). This certainly then affects a total loan volume in that bank, including the amount of loan granted to micro business customers. This decision, to some extent, can be said as a defensive loan strategy or unwillingness to supply loans.

Figure 1

The Pooled of Funds Approach

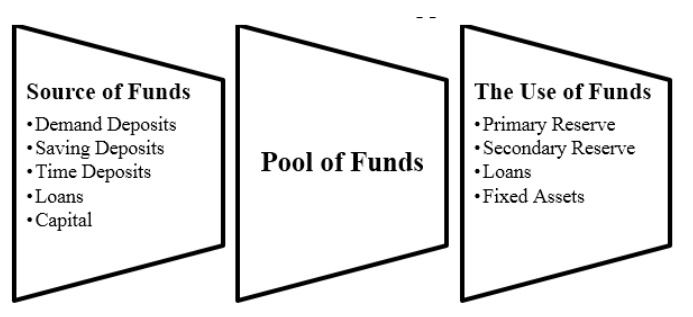

Source: Riyadi, 201o, p. 26

In the literature, this investment behaviour often occurs in some particular conditions, including when bank perceive that external conditions do not indicate a good prospect for loan disbursement (Armstrong, 2013) or when bank feels that loan disbursement is very risky as a result of a decrease in business prospect or business stability in general and so 
forth (Wehinger, 2014; and Dietsch and Petey, 2002). Consequently, the impact of the decision cause deterioration on lending ability. When the collected funds are invested more in other investment portfolios than loan portfolio, the bank may face scarcity of funds to undergo financing activities (Pratama, 2010; Riyadi, 2006; and Gupta and Jain, 2004). In this case, banks could not be able to provide a loan, even though to those customers perceived potentially bankable applicants or worthiness.

Like the use of funds decisions, bank also faces matters when investing funds into loan portfolio. Within the loan portfolio, they have options to finance, and each loan decision made will certainly affect other loan investment decisions (Sudirman, 2003; and Nuswantara, 2012). Among them are to choosing to invest loan portfolio based on span of time such as a short-term loan, mediumterm loan, or long-term loan. It could also occur on the basis of customer categories, like large-size business, medium-size business, small-size business or microsize business (Beck, 2007) or as an option to finance loan based on consumption loan, working capital loan or investment loan. For example, when banks allocate more of their funds into loan portfolio for large-size business and medium size business (Rivai and Veithzal, 2007), they certainly will have a limited amount of funds that can be used to finance small and micro business.

In the case of loan investment decision, it is the fact that literature noted that bank prefers to allocate its funds more to potential customers attached with valuable collaterals such as large-size business (Menkhoff et al., 2006; and Elsas and Krahnen, 2002). Dealing with such customers might give the bank a better confidence to screen the application since such customers usually can meet all documents required at most
(Manove et al., 2001). Besides, it could be that to deal with large customers will make bank to spend less time to evaluate loans due to the possibly complete document attached in their application. As stated by Rivai and Veithzal (2007) that bank will decide to supply loan when bank feels that it can earn a profit and safe to obtain back the loan repayment. This preference decision always occurs, and the most suffers are always to micro business, as they are always treated last alternatives to be chosen for financing.

Unlike large-size business applicants, micro business is often treated riskier customers. They usually do not have proper documents attached in their application. To the fact that many micro businesses do not have business records, collateral, and face uncertainty business activities and to some case, do not have a good intention to make a loan repayment. To bank, dealing with micro business customers is costly as it needs much time to screen and evaluate their application since the amount of fund for micro business is small size nature per customer (Steijvers et al., 2010; and Cao and Shi, 2001). It is therefore that bank would not prefer to serve and provide credit facilities to such customers at most, with the exception in a certain category of banks (Beck, 2007).

It has been stated by an extensive literature that rural banks, and to very few numbers, commercial banks are willing to supply a loan to micro business customers (De la Torre, Pería, and Schmukler, 2010). Rural bank is established mostly to provide credit facilities, including to micro business customers. It is thereby that this bank is categorised as experienced banks to serve the customers, thereby then loan financing made are provided to micro and small businesses at most (Uchida, Udell, and Watanabe, 2008). They, however, use the concept of payday 
loans and charge high interest rates. As consequence, there still many potential customers from micro and small business would not be able to obtain the credit facility.

To a very little extent, literature stated that some commercial banks provide loans to micro and small business. They, however, only provide loans to such customers to avoid being given a penalty by Central Bank when they do not show a certain proportion of loan investment to such business categories in their asset composition. As consequence, many of them provide loan only to satisfy the regulation imposed by the central bank, and it is therefore that they are only willing to serve certain customers, like well-known customers, and/or customers attached with valuable collateral, and/ or customers with a co-signer, and/ or customers having regular saving on bank (civil servants that propose micro and small-business loan for their family business) and others (Riyadi, 2006). This making many researchers feels that banks discriminate against micro and small business customers (Ghezzi, 2012; and Buckley, 1997).

Loan constraints posed by commercial banks to micro can be in form of unmatched between loan granted and loan requested, interest rates, and duration, as well as loan type. Several researchers have investigated that micro businesses obtain an approval below the amount of loan requested (e.g. Steijvers et al. 2010; and Lapar and Graham, 1990). In that situation, some of them reject and withdraw the application, and another accepts the loans (Lapar and Graham, 1990). It is, however, that those who accept the loans, many of them do not be able to make repayment on time. They are hardly able to use the loan as it is proposed since it is not enough to use it, for example, to finance working capital (Lapar and Graham, 1990). This situation is also the same when banks grant the loan in short duration as proposed by the applicants (Ogujiuba, Ohuche, and Adenuga, 2004).

The high-interest rate is often imposed by commercial banks when dealing with micro business customers (Lowe and Rohling, 1992; and Baas and Schrooten, 2006). When banks impose high loan interests, some applicants could shift to other sources of lending institutions (Lowe and Rohling, 1992), whether to shift to other banks (Lam and Burton, 2006) or to other financial institutions (cooperatives, micro lenders, or informal lenders) (Nurmanaf, 2007; and Kauffmann, 2005). This, in turn, will affect numbers of potential applicants applying for a microloan to which could possibly drive down the quality of loan granted (Nugraheni, and Meiranto, 2013).

Another constraint faced by micro business was in form of type of business discriminations. Banks are relatively reluctant to provide loans to a certain type of business as they feel that they are too riskier based on their previous experience dealing with such type of business customers. The literature also noted that banks only prefer to provide loans to micro businesses owned by civil servants that have saving account in the bank as they will be easy to deduct the repayment from their regular wage on the account (Research Development Agency of North Sumatera Province, 2011). This term of loans is called consumption loans, and Central Bank of Indonesia categorises it as microloans.

On the basis of location, loan supply decisions made by commercial banks are more likely to those customers situated in cities than in regencies or in prospect location felt by loan officers. This is particularly true to the regencies indicating poor socio-economic conditions (Irwin and Scott, 2010) like 
those tailored to fishing activities or coastal and island people (Kurniati, 2017, January 21). In the regency scope, banks prefer to provide loans to customers nearby bank branch offices. It is, therefore, that many customers situated in the other districts or in the village are more likely not able to obtain credit facility from the banks. Another point of view from location perspectives, banks are more likely enjoy to provide credits to micro business situated in the market (traditional and modern market) situated in a capital city or capital regency (Research Development Agency of North Sumatera Province, 2011).

The constraints faced by micro business applicants also faced from loan officer perspectives. Since loan officers are afraid to be blamed for a mistake in distributing loan to micro business (Nilsson and Ohman, 2011), their loan supply performance to micro business is suffering. It is particularly true when viewed from loan officer's characteristics like sex, age, and experiences. In sex perspectives, male loan officers are perceived better than female in terms of a number of customers managed, the amount of loan granted, variation in accordance with the type of customers (Beck, Behr, and Madestam, 2011; and Bellucci, Borisov, and Zazzaro, 2010). The condition occurred since males can access many locations driving to attract potential customers widely and are able to provide ease of repayment schedule even until midnight. Unlike female loan officers, they mostly count on applicants nearby bank branch offices and wait for applicants to come to the bank directly.

With respect to loan officer age, younger loan officers with cultural adaptation would perform better than older officers since they have a well physical endurance to attract micro and small business through visiting them regularly on their locations. This would be a challenge for older loan officers. Differently, experienced loan officers are able to manage and identify potential customers well than inexperienced loan officers (Lipshitz, R., \& Shulimovitz, 2007; Jankowicz and Hisrich, 1987; and Miller et al., 1993). Inexperienced loan officers might be very selective and spend more time to process, while experienced loan officers could recognise potential customers in a very short time with less frequency of interactions (Andersson, 2004).

\section{Hypothesis}

External factors could also affect bank's ability to supply loans directly and indirectly as noted by a large body of research literature. External conditions like economic condition may affect bank internally. For instance, when downturn economy occurs, there is a possibility that banks face internal problems such as a liquidity shortage problem and so forth (Woodford, 2010; and Getav et al., 2007). The issue then causes banks to be less able, or reluctant to provide more loans or may impose considerably high loan standards, such as high loan interest (Hubbard et al., 2002), and binding loan policies such as targeted loans only to regular or well-known reputation customers (Lehmann et al., 2004).

\section{$H_{1}$ : The more favourable the external condition, the better the bank internal-specific condition}

Besides affecting lending ability to supply loans, external factors could also affectloanofficerjudgmentanddecision(s) to supply loans. External factors are also part of the main consideration prior to making lending decisions (Sastrosiwito and Suzuki, 2012; and Von and Chan, 2009), as they may contribute to affect credit soundness, which then affects loan officers' performance (Deakins 
and Hussain, 1994). For instance, a bad outlook of the economic condition may decrease the willingness of the loan officers to grant more loans as they are fear of making mistakes and to be blamed when making bad loan quality (Nilson and Ohman, 2011). Additionally, a downturn economic condition may lead to a high probability to select riskier borrowers (Lowe and Rohling, 1992), and probability of borrowers to make loan repayment is very low due to their businesses also affected by the condition (Burton et al., 2003, p. 98).

\section{$H_{2}$ : The better the external condition, the more positive the loan officer judgment and decision(s)}

Similar to the external condition, the internal condition can also influence the decisions made by loan officers. In many cases, the internal bank is often prioritised as one of the considerations that should be satisfied prior to make any decisions, including the decisions to supply loans. As given in the previously, if the soundness of internal bank is good, there is a high probability that loan officers will easily make decisions to supply loans because of internal condition act as a buffer for loan activities and liquidity. Internal factors like fund availability, managerial support, loan plan, loan rate and other internal factors are often taken into account when making lending decision(s) (e.g. Darvas, 2013; Nuswantara, 2012; Blanchflower et al., 2003; Shollapur and Baligatti, 2010).

$\mathrm{H}_{3}$ : The more favourable the bank internal - specific condition, the more positive the loan officer judgment and decision(s)

\section{RESEARCH METHODOLOGY}

The study applies quantitative method using Structural Equation Model (SEM). The structural Equation Model (SEM) is able to solve directional and nondirectional linear relationship among variables that are observable variables or measured variables (MVs) and unobservable variables or latent variable (LVs) or construct(MacCallumandAustin 2000; Schumacker and Lomax 2010; and Waluyo 2009). In addition, according to Ferdinand (2002), SEM is a combination of factor and regression analysis. SEM test allows the researchers to test several dependent variables simultaneously. This tool is a set of statistical tools that can be used to analyze the research issues that have a series relationship that is relatively complicated with statistical test simultaneously.

Aside from SEM, the study also tests all variable using Confirmatory Factor Analysis (CFA). This factor analysis is used to minimize the number of variables while also maximizing the amount of information in the analysis (Tran, 2010). This factor analysis is used to test variance, the reliability of construct and loading weight parameter for each indicator. Normally factors an eigenvalue of greater than one are viewed as surrogate factors and they are chosen in the analysis (Hair et al, 2006). In relation to loading factor, loading weight parameter greater than at least 0.50 are suggested and very significant for the analysis with $t$ value of a loading factor greater than its critical value (or $>$ 1.96) (Said et al. 2001; and Bagozzi and Yi,1998). The study refers to variance extracted greater than 0.50 as cited by Hair et al (1998) cited in Wijanto (2008, p66), while a construct reliability is 0.60 (Said et al 2001 and Dewi, 2009). 
Figure 2

The Conceptual Model

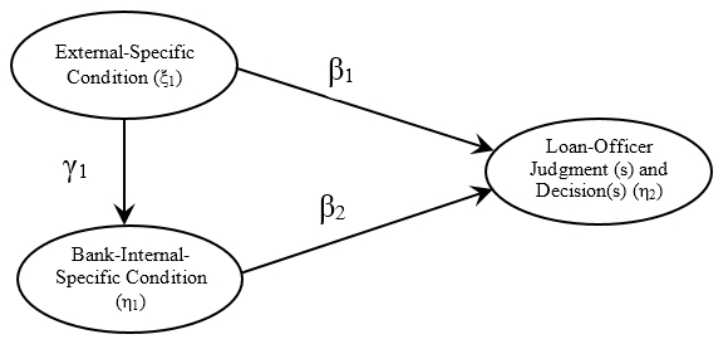

\section{RESPONDENTS AND UNIT ANALYSIS}

To respondent information, the study obtains information from 122 microloan officers (Mantri) assigned in state and regional development banks in 27 regencies/cities within the province of South and West Sulawesi. Of the respondents, as many as 91 (74.59\%) are male, and $31(25.41 \%)$ are female. With respect to the age group with five classifications, $27(22.13 \%)$ were aged less than or equal to 25 years old, 64 (52.46\%) were aged between 26 to 30 years old, 21 (17.21\%) were aged between 30 to 35 years old, 5 (4.10\%) were aged between 36 to 40 years old, and 4 (3.28\%) were aged above 40 years old. Only 1 did respondent not fill the instrument given. Viewed from bank branch categories, 13 (10.66\%) were from five different regional development banks and 109 (89.34\%) were from four different state banks. To bank status, 6 (4.92) were from the main branches, 30 (24.59\%) were branches, 14 (11.48\%) were from sub-branches, and 72 (59.02\%) were from cash/unit offices.

The study uses five Liker scale. The Likert scale permits mathematical operation of computing a mean and standard deviation, which is very useful to solve problems in SEM (Structural Equation Model) (Schumacker and Lomax 2010 p19). The advantage of Likert scale is also mentioned by Saunders et al. (2007) as cited in Al Mamun (2012) who argue that Likert scale presents a load of data for conducting the research in a limited time and is able to analyse effectively. The sample size used in this study is 197 samples from those credit officers assigned in bank branch level in cities and regencies within the Province of South and West Sulawesi.

\section{LISREL PROGRAM}

The data have been analyzed using LISREL Program 9.2 method, a modeling method using structural equation. The advantage of this program lies in the program's ability to test the significances of indicators and construct simultaneously across the model. The program provides warnings if there are interrelationships between constructs that have not been suggested in the original model (Berggren et al. 2000).

Operationalization of the model

$\xi=$ The External-Specific Condition (EXT)

$\mathrm{X}_{1}=$ Competition

$\mathrm{X}_{2}=$ Regional Economic Condition

$\mathrm{X}_{3}=$ Socioeconomic Condition

$\mathrm{X}_{4}^{3}=$ Market Size Condition

$\eta_{1}^{4}=$ The Internal-Specific Condition (INT)

$\mathrm{Y}_{1.1}=$ Fund availability

$\mathrm{Y}_{1.2}=$ Loan Plan

$\mathrm{Y}_{1.3}^{1.2}=$ Managerial Decision

$\mathrm{Y}_{1.4}^{1.3}=$ Loan Cost

$\eta_{\mathbf{2}}^{1.4}=$ The Loan-Officer Judgment and Decision(s) (LOJD)

$\mathrm{Y}_{2.1}=$ Fund availability

$\mathrm{Y}_{2.2}^{2.1}=$ Loan Plan

$\mathrm{Y}_{2.3}^{2.2}=$ Managerial Decision

$\mathrm{Y}_{2.4}^{2.3}=$ Loan Cost

Where,

$\xi_{1}=$ Exogeneous variables

$\eta=$ endogeneous variables

$\mathrm{X}_{1}-\mathrm{X}_{4}=$ Indicator for exogeneous variables

$\mathrm{Y}_{1.1}-\mathrm{Y}_{1.4}=$ Indicator for endogeneous 
variables

$\mathrm{Y}_{2.1}-\mathrm{Y}_{2.4}=$ Indicator for endogeneous variables

$\mathrm{Lx}_{1}-\mathrm{Lx}_{4}=$ Loading Factor for exogeneous indicators

$\mathrm{Ly}_{1.1}-\mathrm{Ly}_{1.4}=$ Loading Factor for endogeneous indicators

$\mathrm{Ly}_{2.1}-\mathrm{Ly}_{2.4}=$ Loading Factor for endogeneous indicators

$\mathrm{e}_{\mathrm{x} 1}-\mathrm{e}_{\mathrm{x} 4}=$ error for exogeneous indicators

$\mathrm{e}_{\mathrm{y} 1.1}-\mathrm{e}_{\mathrm{y1} .4}=$ error for endogeneous indicators

$\mathrm{e}_{\mathrm{y} 1.2}-\mathrm{e}_{\mathrm{y} 2.4}=$ error for endogeneous indicators

Structural coefficients for different pairs of the path model latent (construct) factors are:

$\gamma=$ for the external-specific condition/ the internal-specific condition relationship

$\beta_{1}=$ for the external-specific condition/ the loan-officer judgment and decision(s) relationship

$\beta_{2}=$ for the internal-specific condition/ the loan-officer judgment and decision(s) relationship

Based on the model given, the equations to represent the models are given as follow

$\eta_{1}=f_{1}\left(\xi_{1}\right)$

$\eta_{2}=f_{2}\left(\xi_{1}, \eta_{1}\right)$

where,

$\eta_{1}=\gamma_{0}+\gamma_{1} \xi_{1}+e_{1}$

$$
\eta_{2}=\beta_{0}+\beta_{1} \xi_{1}+\beta_{2} \eta_{1}+e_{2}
$$

The research design uses three latent variables that consist of one exogenous variable and two endogeneous variables. The whole latent variables are constructed by 12 indicators, of which four exogenous indicators and eight endogenous indicators (see the table 1). The Exogeneous latent variable of the external-specific condition is defined by $\mathrm{X}_{1}$ (competition), $\mathrm{X}_{2}$ (regional economic condition), $\mathrm{X}_{3}$ (socioeconomic condition) and $\mathrm{X}_{4}$ (market size condition). The internal-specific condition is defined by $\mathrm{Y}_{1.1}$ (fund availability), $\mathrm{Y}_{1.2}$ (managerial decision), $Y_{1.3}$ (loan plan strategies), $Y_{1.4}$ (interest rate) and the loan-officer judgment and decision(s) is defined by $\mathrm{Y}_{2.1}$ (loan officer confidence), $\mathrm{Y}_{2.2}$ (financial incentives), $Y_{2.3}$ (loan officer capacity), $\mathrm{Y}_{2.4}$ (loan officer experience).

\section{RESULT AND ANALYSIS}

To test SEM assumption for the model, the study tests normality, outlier and multicollinearity evaluation. On the basis of the statistical test, the distribution of data shows normality trend indicated in the trend display of Q-plots of standardized residual (see annex 2). Outlier identification using statistical test using $d^{2}$ (Mahalanobis Distance) applying SPSS program 23 indicates that

Table 1

Measurement Model for the Proposed Research Design

\begin{tabular}{ll}
$\begin{array}{l}\text { EXOGENEOUS INDICATORS } \\
\text { (MEASUREMENT MODEL) }\end{array}$ & $\begin{array}{l}\text { ENDOGENEOUS INDICATORS } \\
\text { (MEASUREMENT MODEL) }\end{array}$ \\
\hline $\mathrm{X}_{1}=\mathrm{Lx}_{1} * \xi+\mathrm{e}_{\mathrm{x} 1}$ & $\mathrm{Y}_{1.1}=\mathrm{Ly}_{1.1} * \mathrm{\eta}_{1}+\mathrm{e}_{\mathrm{y} 1.1}$ \\
$\mathrm{X}_{2}=\mathrm{Lx}_{2} * \xi+\mathrm{e}_{\mathrm{x} 2}$ & $\mathrm{Y}_{1.2}=\mathrm{Ly}_{1.2} * \eta_{1}+\mathrm{e}_{\mathrm{y} 1.2}$ \\
$\mathrm{X}_{3}=\mathrm{Lx}_{3} * \xi+\mathrm{e}_{\mathrm{x} 3}$ & $\mathrm{Y}_{1.3}=\mathrm{Ly}_{1.3} * \mathrm{\eta}_{1}+\mathrm{e}_{\mathrm{y} 1.3}$ \\
$\mathrm{X}_{4}=\mathrm{Lx}_{4} * \xi+\mathrm{e}_{\mathrm{x} 4}$ & $\mathrm{Y}_{1.4}=\mathrm{Ly}_{1.4} * \eta_{1}+\mathrm{e}_{\mathrm{y} 1.4}$ \\
& $\mathrm{Y}_{2.1}=\mathrm{Ly}_{2.1} * \mathrm{\eta}_{2}+\mathrm{e}_{\mathrm{y} 2.1}$ \\
& $\mathrm{Y}_{2.2}=\mathrm{Ly}_{2.2} * \mathrm{\eta}_{2}+\mathrm{e}_{\mathrm{y} 2.2}$ \\
& $\mathrm{Y}_{2.3}=\mathrm{Ly}_{2.3} * \eta_{2}+\mathrm{e}_{\mathrm{y} 2.3}$ \\
& $\mathrm{Y}_{2.4}=\mathrm{Ly}_{2.4} * \eta_{2}+\mathrm{e}_{\mathrm{y} 2.4}$
\end{tabular}


there was an outlier data on the listed respondent. Referring to an acceptable range for the minimum Mahalanobis Distance, which is 2.366, the respondent in the row five show below the minimum cut-off value that is 2.36581 . It is therefore that the study drops the outlier respondent. To multicollinearity test, LISREL program 9.2 automatically do not detect multicollinearity.

In relation to test of the goodness of fit indexes as given in table 2 below, the study evaluates some overall statistical goodness indexes in accordance with the output of the LISREL program 9.2. With regard to model-fit criteria using criteria of chi-square $\left(\chi^{2}\right)$, the goodness-of-fit index (GFI), the adjusted goodness-offit index (AGFI), and root-mean-square residual index (RMR) (Joreskog \& Sorbom, 1989 cited in Schumaker and Lomax, 2010; p85), the result indicated that the sample variance-covariance data fit the structural equation model. The chi-square result shows a significant score as the $\mathrm{p}$-value of 0.6803 is greater than $0.05(0.683>0.05)$ or with the confidence $95 \%$, chi-square value is less than chi-square table $(45.78<68.67)$. To AGFI and GFI, they also show a good rate of fit as both scores are greater than 0.90. For RMR, it also indicates a good rate of fit as the score is less than 0.05 (0.0244 $<0.05$ ).

To other model-fit criteria, incremental fit index (IFI), relative fit index (RFI), root-mean square error of approximation (RMSEA), the results for IFI and RF indices show greater scores than 0.90 , while the score of RMSEA is less than $0.008(0.002<0.008)$. It is then considered the model has a good fit rate.

With respect to the model-comparison criteria using Tucker-Lewis Index (TLI) initiated by Tucker and Lewis (1973

Table 2

Overall Statistical Goodness of Indexes with SEM Model

$\begin{array}{ccc}\text { Model-Fit Criterion } & \text { Estimate Results } & \text { Rate of fit } \\ \text { Chi-square } & 45.78(45.78<68.67) \text { or } \mathrm{P}=0.6803 & \text { Good } \\ \text { Goodness-of-fit Index (GFI) } & >0.05) & \text { Good } \\ \text { Adjusted GFI (AGFI) } & 0.945(0.945 \geq 0.90) & \text { Good } \\ \text { Standardized RMR (SRMR) } & 0.941(0.916 \geq 0.90) & \text { Good } \\ \text { Root-mean-square error of approximation } & 0.0244(0.0244<0.05) & \text { Good } \\ \text { Expected Cross-Validation Index (ECVI) } & 0.861(0.8620 .861 \text { than to } 0.976) & \text { Good } \\ \text { Normed fit index (NFI) } & 0.949(0.949 \geq 0.95) & \text { Good } \\ \text { Tucker-Lewis index (TLI) / Non Normed } & 1.000(1.000 \geq 0.95) & \text { Good } \\ \text { Rel index (NNFI) } & 0.934(0.990 \geq 0.95) & \text { Good } \\ \text { Incremental fit index (IFI) } & 1.000(1.000 \geq 0.95) & \text { Good } \\ \text { Comparative fit index (CFI) } \\ \text { Critical N (CN) }\end{array}$


Figure 3.

Path SEM Model

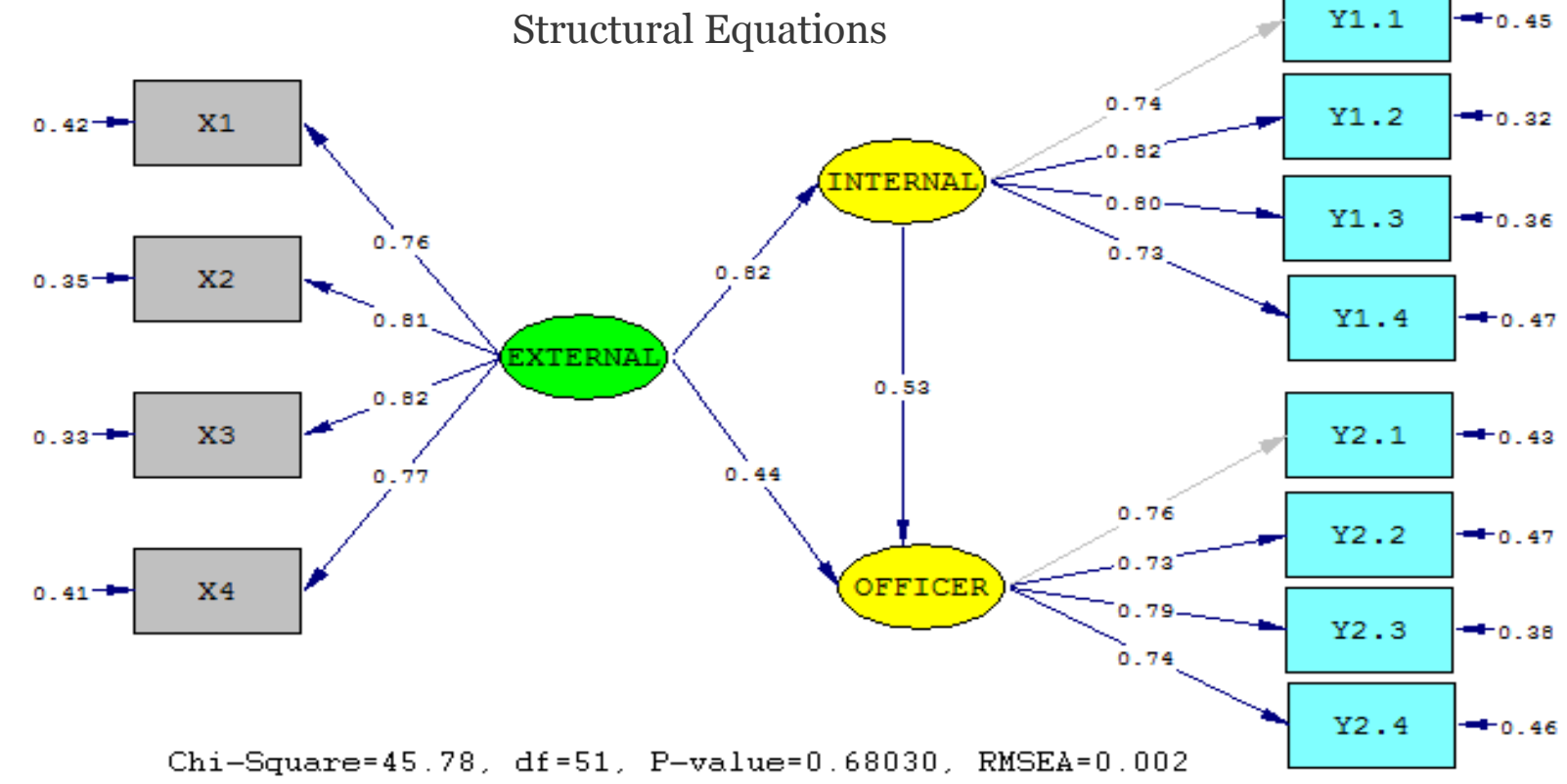

cited in Schumacker and Lomax, 2010 p88), normed fit index (NFI) and the comparative fit index (CFI) developed by Bentler \& Bonett, 1980 cited in Schumacker nd Lomax, 2010 p88), the result indicated that those three modelcomparison criteria score above 0.95 . thus, the result can be said that the model is different with the null model.

The last is $\mathrm{CN}$ evaluation. The value of $\mathrm{CN}=205.532$ is greater than 200 indicating that the model can be used to represent the data sample.

Figure 1 graphs a path of statistical results for three latent variables with twelve observed variables. The exogenous construct of the external-specific condition is defined by four observed variables, which are $\mathrm{X}_{1}$ (competition condition), $\mathrm{X}_{2}$ (economic condition), $\mathrm{X}_{3}$ (socio-economic condition), and $\mathrm{X}_{4}$ (market-size Condition). The endogenous construct of the internal-specific condition is also defined by four observe variables that are $Y_{1.1}$ (fund availability), $Y_{1.2}$ (loan plan), $Y_{1.3}$ (loan rate), and $Y_{1.4}^{1.2}$ (managerial decision), and for the construct of loan-officer judgment(s) and decision(s) is also defined by four which are $Y_{2.1}$ (LO confidence), $Y_{2.2}$ (financial incentives), $\mathrm{Y}_{2.3}$ (LO capability), and $\mathrm{Y}_{2.4}$ (LO experience).

On the basis of Structural Equation model using the LISREL Program 9.2, the statistical result of the program indicated that all of three relationships show a positive coefficient path-parameter result. With regard to the relationship between the external-specific condition and the internal-specific condition, the coefficient parameter is 0.82 and $t$-value are 7.63. Since the t-value also shows a good score (7.63), which is above a critical value (1.96), it can then be said that there is a positively significant relationship between the external-specific condition and the internal-specific condition. To another correlation covariance, the association between the externalspecific condition and the loan-officer judgment(s) and decision(s) also show a positively significant relationship with the coefficient parameter is 0.44 and $\mathrm{t}$-value are 3.11. Similarly, the association between the internal-specific condition and the loan-officer judgment(s) and decision(s) with a coefficient parameter 
0.53 indicate a significant relationship with t-value is 3.52. Of these relationships, it can then be said that it accepts the hypothesis alternatives for this three relationship.

$\begin{array}{cc}\text { INTERNAL }= & 0.822^{*} \text { EXTERNAL, } \\ \text { Errorvar. }=0.324, \mathrm{R}^{2}=0.676 \\ \text { Standerr }(0.108) & (0.0916) \\ \text { Z-values } 7.626 & 3.538 \\ \text { P-values } 0.000 & 0.000\end{array}$

OFFICER = $0.526 *$ INTERNAL + 0.442*EXTERNAL, Errorvar.= 0.145 , $\mathrm{R}^{2}=0.855$

Standerr (0.149) (0.142) (0.0580)

$\begin{array}{llll}\text { Z-values } & 3.523 & 3.105 & 2.495\end{array}$

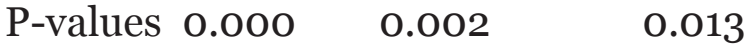

NOTE: $\mathrm{R}^{2}$ for Structural Equations are Hayduk's (2006) Blocked-Error R ${ }^{2}$

Reduced Form Equations

INTERNAL $=0.822 *$ EXTERNAL, Errorvar. $=0.324, \mathrm{R}^{2}=0.676$

Standerr (0.108)

Z-values 7.595

P-values 0.000

\author{
OFFICER $=0.875^{*}$ EXTERNAL, \\ Errorvar. $=0.234, \mathrm{R}^{2}=0.766$ \\ Standerr (0.106) \\ Z-values 8.219 \\ P-values 0.000
}

On the basis of the given path model, as shown in figure 3 above, there are two structural equation results that the internal-specific condition and the loanofficer judgment(s) and decision(s). From the result, it can be said that the structural equation for the latent variable of the internal-specific condition has $67.6 \%$ of its variance predicted ( $\mathrm{R} 2$ 0.676) with 28.8\% unexplained error variance due to the random or systematic error of other indicator or variables not included in the model. To structural equation of the loan-officer judgment(s) and decision(s), the equation has $76.6 \%$ of its variances and $28.9 \%$ unexplained due to random or systematic error or others or variables that may not be included in the model.

With respect to Confirmatory Factor Analysis (CFA) test, the observed variables within the latent variables studied indicate acceptable score results. All three latent variables, the external-specific condition, the internalspecific condition and the loan-officer judgment(s) and decision(s), have loading-factor parameter above an acceptable level. The statistical analysis result for the loading parameter indicated a good validity in which the standardised loading parameter scores shows above acceptable value recommended by Ridgon and Ferguson (1991) and Hair et. al. (1995) that are respectively 0.70 and 0.50 . In relation to t-value scores for the loading and residual parameter, the scores lie above the critical value, at $\mathbf{1 . 9 6}$ or 2.

To reliability evaluation, construct reliability (CR) and extract variance (VE) indicate a good reliability for the latent variable of the external-specific condition, whether referring to Bagozzi and $\mathrm{Yi}$ (1998) and Hair et al. (1998), which is greater than 0.70 for construct reliability and 0.50 for extract variance. The CR score as given in table 1 (0.8679>0.70) is greater than the cut value. This is also valid for extract variance (VE) evaluation (0.6221 > 0.50).

Model-fit criteria for the goodness of fit indexes indicates a well fitting model (Bentler, 1990) for the external-specific condition. Chi-Square is a good rate of fit as the score of 1.61 is less than chi-square table or p-value 0.4480 is greater than 0.05. The goodness-of-fit index (GFI) and the adjusted goodness-of-fit index (AGFI) also show good as the scores are greater than 0.90. , incremental fit index (IFI), relative fit index (RFI), root-meansquare residual index (RMR), and root- 
Hasanuddin Economics and Business Review

Vol. 1 No. 2 (90-113)

Table 3

Summary: Parameter Estimation Result for the External Condition Measurement Model (Standardized, $\mathrm{n}=121$ )

\begin{tabular}{lllll}
\hline Indicator & $\boldsymbol{\Lambda}$ & $\mathrm{t}^{* *}$ & $\mathbf{R}^{\mathbf{2}}$ & Error Var $^{* *}$ \\
\hline Competitive Condition $\left(\mathrm{X}_{1}\right)$ & 0.75 & 9.26 & 0.568 & 0.43 \\
Regional Economic Condition $\left(\mathrm{X}_{2}\right)$ & 0.84 & 10.84 & 0.711 & 0.29 \\
Socio-economic Condition $\left(\mathrm{X}_{3}\right)$ & 0.81 & 10.22 & 0.654 & 0.35 \\
Market Size Condition $\left(\mathrm{X}_{4}\right)$ & 0.75 & 9.13 & 0.556 & 0.44 \\
$\sum \lambda$ & 3.15 & & & \\
$\sum$ Error Variance & & & & 1.51 \\
Reliability Construct & & & & 0.8679 \\
Variance Extracted & & & 0.6221 \\
$*$ * P $<$ 0.001 & & & \\
\hline
\end{tabular}

mean square error of approximation (RMSEA) also show a good rate of fit. For the IFI and RFI, they score above 0.95 . To RMR and RMSEA, the RMR's score of 0.0142 is less than 0.05 and RMSEA's score of 0.0107 is less than 0.08. Thus, it can be said that the sample variancecovariance data fit the equation model.

In relation to the latent variable of the internal-specific condition, reliability evaluation with the use of construct reliability (CR) and extract variance (VE) also indicate good reliability scores for the latent variable. The CR score as given in table 2 ( $0.8564>0.70)$ is greater than the cut value. This is also valid for extract variance (VE) evaluation (0.5999
$>0.50)$.

The goodness of fit indexes for the construct also shows a well fitting model (see annex 3). Chi-Square is a good rate of fit as the score of 0.910 is less than chisquare table or p-value 0.63432 is greater than 0.05. The goodness-of-fit index (GFI) and the adjusted goodness-of-fit index (AGFI) also show good as the scores are greater than 0.90. , incremental fit index (IFI), relative fit index (RFI), rootmean-square residual index (RMR), and root-mean square error of approximation (RMSEA) also show a good rate of fit. For the IFI and RFI, they score above 0.95 . To RMR and RMSEA, the RMR's score of 0.0109 is less than 0.05 and RMSEA's

Table 4

Summary: Parameter Estimation Result for the Internal Condition Measurement Model (Standardized, $\mathrm{n}=121$ )

\begin{tabular}{|c|c|c|c|c|}
\hline Indicator & $\boldsymbol{\Lambda}$ & $t^{* *}$ & $\mathbf{R}^{2}$ & Error Var** \\
\hline Fund Availability $\left(\mathrm{Y}_{1.1}\right)$ & 0.72 & 8.62 & 0.517 & 0.48 \\
\hline Loan Plan $\left(\mathrm{Y}_{1.2}\right)$ & 0.82 & 10.27 & 0.669 & 0.33 \\
\hline Loan Rate $\left(\mathrm{Y}_{1.3}\right)$ & 0.81 & 10.19 & 0.661 & 0.34 \\
\hline Managerial Decisions $\left(\mathrm{Y}_{1.4}\right)$ & 0.74 & 9.04 & 0.555 & 0.45 \\
\hline$\sum \lambda$ & 3.09 & & & \\
\hline$\sum$ Error Variance & & & & 1.6 \\
\hline Reliability Construct & & & & 0.8564 \\
\hline Variance Extracted & & & & 0.5999 \\
\hline
\end{tabular}

** $\mathrm{P}<0.001$ 
score of 0.00758 is less than 0.08. Thus, it can be said that the sample variancecovariance data fit the equation model.

With respect to the loan-officer judgment(s) and decision(s), reliability evaluation with the use of construct reliability (CR) and extract variance (VE) also indicate good reliability scores for the latent variable. The $\mathrm{CR}$ score as given in table 2 (0.8405>0.70) is greater than the cut value. This is also valid for extract variance (VE) evaluation (0.5688 $>0.50$ ).

To evaluation of the goodness of fit indexes for the construct. The goodness of fit indexes for the construct also shows a well fitting model (see annex 4). ChiSquare is a good rate of fit as the score of 0.910 is less than chi-square table or p-value 0.63432 is greater than 0.05. The goodness-of-fit index (GFI) and the adjusted goodness-of-fit index (AGFI) also show good as the scores are greater than 0.90. , incremental fit index (IFI), relative fit index (RFI), root-mean-square residual index (RMR), and root-mean square error of approximation (RMSEA) also show a good rate of fit. For the IFI and RFI, they score above 0.95. To RMR and RMSEA, the RMR's score of 0.0109 is less than 0.05 and RMSEA's score of 0.00758 is less than 0.08. Thus, it can be said that the sample variance-covariance data fit the equation model.

\section{DISCUSSION}

Prior to making loan supply decision, loan officers assigned in commercial bank branches for state and regional banks are affected by three conditions. These conditions are the externalspecific condition, the internal-specific condition, and the loan officer itself. These three variables can be shown in an integrated model for SEM.

With SEM path model, the externalspecific condition affects positively and significantly the internal-specific condition, and the external-specific condition also affects positively and significantly the loan officer judgment(s) and decision(s), the internal-specific condition affects positively and significantly the loan officer judgment(s) and decision(s) as well. This indicates that when the external condition is positive, the bank internal-specific condition is also positive and the loanofficer judgment and decision(s) could also be positive. It also true when the internal condition is positive, the more positive the loan officer judgment and decision(s).

The observed variables of the

Table 5

Summary: Parameter Estimation Result for the Loan-Officer Judgment and Decision(s) Measurement Model (Standardized, $\mathrm{n}=121$ )

\begin{tabular}{lllll}
\hline Indicator & $\boldsymbol{\Lambda}$ & $\mathrm{t}^{* *}$ & $\mathbf{R}^{2}$ & Earö \\
\hline Loan-Officer Confidence $\left(\mathrm{Y}_{2.1}\right)$ & 0.76 & 9.09 & 0.575 & 0.43 \\
Financial Incentives $\left(\mathrm{Y}_{2.2}\right)$ & 0.72 & 8.48 & 0.517 & 0.48 \\
Loan-Officer Capability $\left(\mathrm{Y}_{2.3}\right)$ & 0.79 & 9.60 & 0.623 & 0.38 \\
Loan-Officer Experience $\left(\mathrm{Y}_{2.4}\right)$ & 0.75 & 8.90 & 0.555 & 0.44 \\
$\sum \lambda$ & 3.02 & & \\
$\sum$ Error Variance & & & \\
Reliability Construct & & & 0.73 \\
Variance Extracted & & & 0.5688 \\
$* *$ P $<$ 0.001 & & & & \\
\hline
\end{tabular}


competition condition, the economic condition, the socio-economic condition, and the market-size condition can be used to predict the construct of the externalspecific condition. The highest loading parameter is socio-economic condition and economic condition. This could be said that the loan officers assigned for micro business were afraid to distribute microloan to business customers situated in poor socio-economic condition or they may apply defensive loan strategies in such condition. It is also valid when the economic condition did not show a good sign.

The factors like the fund availability, the loan plan, the loan rate, and the managerial decision can be used to define the construct of the internalspecific condition. The highest loading weight parameter is loan plan and loan rate. This could occur since loan plan and loan rate could make loan officers to selectively supply loans to certain micro business applicants only. When a loan policy at the bank branch level is tightly enough, the loan officers would provide loan supply decision to certain customers only or to well-known customers only. To loan rate, this could make loan officers to not be able to supply loans to potential customers as when loan rate is high, there is a possibility that loan officers will book a loan default or loan officers would be difficult to attract potential customers.

With respect to loan officer indicators, loan-officer confidence, financial incentives, loan officer capacity and loan officer experience can be used to define the construct of the loanofficer judgment(s) and decision(s). It is not surprising to know that loan officer capability is the highest loading parameter in the construct. As capability could make a loan officer be able to book high loan supply decision. To confidence, it is true that the loading weight parameter possibly high since many micro businesses have improper information on their application. Thus, each loan officer should be able to judge and select potential customer confidently.

\section{IMPLICATION}

Generally, it can be said that loan officers assigned in state banks or in regional development bank branches face matters when assessing loans for micro businesses. There is a possibility to restrict loan supply to micro businesses and making a loan only to certain customers due to a high attention given on the external condition, the internal condition, and the loan officer features.

When viewed from the external factors, it suggests that loan officers are relatively reluctant to supply loan decisions to micro business customers situated in areas with a poor socio-economic condition or when the economic condition shows a downturn. This implies that loan officers are relatively afraid to take a risky decision and to be blamed for a default booked. It could be that it is due to high business fluctuation and unpredictable continuity owned by those customers. It also could be due to hardly able to judge a potential customer on the basis of limited information obtained from that business.

Even though there are constraints, but loan officers still perceived that microbusiness customers are potential enough. The result is corresponding with the fact that numbers of micro customers are more than other business customers. This could imply that the loan officers would still expand more loan to micro business customers, but restricted to well-known customers or certain customers only.

Related to the internal aspect, loan officers give much attention to the loan rate and the loan plan relative to other two variables. It can be said that loan officers were struggling to provide a loan 
when there was not a support from bank branches and/or when the loan rate was high. This could certainly imply that there is a different approach applied by each bank branch to the which then affect loan supply decision made by a loan officer at bank branch level. This condition could be occurred due to a different risk perception for a different area such differences as socioeconomic condition, customer character and so forth. To loan rate, it indicates that there is a competition to affect potential customers in selecting a bank to apply for a loan.

With respect to features of the loan officer, loan officer capacity and confidence are dominant. It could imply that loan officers count mostly on the flow of information obtained from applicants. When information is not enough yet to assess the application, the loan officer would count on their confidence in making loan supply decision.

\section{REFERENCES}

Andersson, P., "Does Experience Matter in Lending? A Process-Tracing Study on Experienced Loan Officers and Novices Decision Behaviour," Journal of Economic Psychology, 4 (2004), 25: 471-492.

Armstrong, A. "Evaluating Changes in Bank Lending to UK SMEs over 2001-2012 - Ongoing Tight Credit," Department for Business Innovation \& Skills, National Institute of Economic and Social Research, (London 2013) Available at https://www.gov.uk/government/uploads/system/uploads/ attachment_data/file/193945/ bis-13-857-evaluating-changes-inbank-lending-to-uk-smes-2001-12. pdf, [Accessed on 18 October 2015]. Anggraini, D., \& Nasution, S. H., Peranan kredit usaha rakyat (KUR) bagi pengembangan UMKM di

Kota Medan (studi kasus Bank BRI). Ekonomi dan Keuangan, (2013) 1 (3). 105 -116.

Baas, T., and Schrooten, M., "Relationship Banking and SMEs: A Theoretical Analysis", Small Business Economics, (2-3), (2006) 27, 127-137.

Bagozzi, R.P., and Yi, Y., "On the Evaluation of Structural Equation Model," Journal of the Academic of Marketing Science Spring, no 1 (1998), vol 16, 074-094

Beck, T. H. L., Behr, P., and Madestam, A., "Sex and Credit: Is There a Gender Bias in Microfinance?," Tilburg University, (2011).

Belluci, A.; Borisov, A.; Zazzaro, A., "Does Gender Matter in Bank-Firm Relationships? Evidence from Small Business Lending”, Journal of Banking \& Finance, no 12, (2010), vol 34, 2968-2984.

Berggren, B., Olofsson, C., \& Silver, L. (2000). Control aversion and the search for external financing in Swedish SMEs. Small Business Economics, no 3. (2000). Vol 15, 233-242.

Blanchflower, D.G., Levine, P.B., and Zimmerman, D.J., "Discrimination in The Small Business Credit Market", Review of Economic and Statistics, no 4, (2003), vol 85, 930 943.

Buckley, G., "Microfinance in Africa: Is it Either the Problem or the Solution?", World Development., no 7, (1997), vol 25, 1081 - 1093 .

Darvaz, Z., "Banking System Soundness is the key to more SME financing," Working Paper of Directorate Generalfor Internal Policies, Policy Department $A$ : Economic and Scientific Policy, Brugel Policy Contribution 2013), Available at http://www. europarl.europa.eu/document/activities/cont/201307/20130712AT- 
T69731/20130712ATT69731EN. pdf, [Accessed on 16 October 2015].

De la Torre, A., Pería, M. S. M., and Schmukler, S. L., "Bank involvement with SMEs: Beyond relationship lending”, Journal of Banking \& Finance, no 9, (2010), vol 34, 2280-2293.

Dewi, Chandra., "Faktor-Faktor Yang Mempengaruhi Pemberian Kredit dan Dampaknya Terhadap Non-performing Loan Studi Kasus Bank Perkreditan Rakyat Propinsi Jawa Tengah", Unpublished Thesis, Magister Management Diponegoro University, (Indonesia 2009).

Dietsch, M., and Petey, J., "The Credit Risk in SME Loans Portfolios: Modelling Issues, Pricing, and Capital Requirements", Journal of Banking \& Finance, no 2, (2002), vol 26, 303-322.

Elsas, R., and Krahnen, J.P., "Collateral, relationship Lending and Financial Distress: An Emperical Study on Financial Contracting", Working Paper Series of Goethe-Universitat Frankfurt, (2002).

Getav E., Schuermann, Til., and Strahan, P. "How Do Banks Manage Liquidity Risk? Evidence from Equity and Deposit Markets in the Fall of 1998", The Risk of Financial Institution, University of Chicago Press, (2007), 105-132.

Gupta, V. and Jain, P.K., "Liability Management in Commercial Banks in India: A Comparative Study of Bank Groups in Liberalized-Era", Global Journal of Flexible System Management, no 4, (2004), vol 5, 53-66.

Hair Jr, J.F., Black, W.C., Babin, B.J., and Anderson, R.E., "Multivariate Data Analysis: A Global Perspective", $7^{\text {th }}$ Edition, United State of America, (Pearson Prentice Hall 2010).
Hubbard, R. G., Kuttner, K.N., and Palia, D.N., "Are there Bank Effects in Borrowers' Cost of Funds? Evidence from a Matched Sample of Borrowers and Banks", Journal of Business, no 4, (2002), vol 75, 559 -581 .

Irwin, D., and Scott, J. M., "Barriers Faced by SMEs in Raising Bank Finance", International Journal of Entrepreneurial Behaviour \& Research, no 3, (2010), vol 16, 245259.

Jankowicz, A. D., \& Hisrich, R. D. (1987). Intuition in small business lending decisions. Journal of Small Business Management, 25 (1987). Vol $3,45^{-52}$

Kurniati, Dian (2017, Januari 21) Butuh Kredit Bunga Rendah? Pemerintah Siapkan 110 Triulun untuk KUR. KBR.Id. Available at http://kbr. id/berita/o1-2017/butuh_kredit_bunga_rendah__pemerintah_siapkan__110_triliun_untuk_kur/88277.html [ accessed on January 24, 2017).

Lam, R., and Burton, S., "SME banking loyalty (and disloyalty): a qualitative study in Hong Kong", International Journal of Bank Marketing, no 1, (2006), vol 24, 37-52.

Lapar, M.L.A. and D.H. Graham, "Credit Rationing under a Deregulated Financial System: Rural Finance in The Philippines," Working Paper Series No. 88 - 19, (1990), Available at https://kb.osu.edu/dspace/ bitstream/handle/1811/66195/ CFAES_ESO_1687.pdf?sequence $=1$, [Accessed on October 28 2015].

Lehmann, Alexander. "Sovereign Credit Ratings and Private Capital Flows to Low $\square$ income Countries." African Development Review 16 (2004). Vol 2, 252-268.

Lipshitz, R., \& Shulimovitz, N. Intuition 
and emotion in bank loan officers' credit decisions. Journal of Cognitive Engineering \& Decision Making, (2007), Vol 1, 212-233.

Lowe, P., and Rohling, T., "Loan Rate Stickiness: Theory and Evidence", Working Paper Series of Reserve Bank of Australia, (1992).

Machmud, Z., \& Huda, A., SME's Access to Finance: An Indonesia Case Study. ERIA Research Project Report 2010, (2011). 14, 261-290.

Manove, M.; Padilla, A.J.; and Pagano, M., "Collateral versus Project Screening: A Model of Lazy Banks", RAND Journal of Economics, no 4, (2001), vol 32, $726-744$.

Menkhoff, L., Neuberger, D., and Suwanaporn, C., "Collateral-Based Lending in Emerging Markets: Evidence from Thailand", Journal of Banking \& Finance, no 1, (2006), vol 30, 1-21.

Meydianawathi, K. (2007). Analisis Perilaku Penawaran Kredit Perbankan Kepada Sektor UMKM di Indonesia. Media Pustaka, 2(1).

Miller, J.R., Reed, S.A., and Strawser, R. H., "Bank Loan Officer Perceptions of the New Audit reports", American Accounting Association, Accounting Horizons, no 1, (1993), vol 7, 39-52.

Nilsson, A., and Ohman, P., (2011), "Better Safe than Sorry: Defensive Loan Assessment Behaviour in a Changing Bank Environment”, Conference on Performance Measurement and Management Control, Nice, France, (2011).

Nugraheni, P.P., and Meiranto, W., "Pengaruh Faktor Internal Bank dan Sertifikat Bank Indonesia terhadap Penyaluran Kredit Perbankan di Indonesia”, Diponegoro Journal of Accounting, no 4, (2013), vol 2,1 -11 .

Nurmanaf, A.R., "Lembaga Informal
Pembiayaan Mikro Lebih Dekat dengan Petani”, Analisis Kebijakan Pertanian, no 2, (2007), vol 5, 99109.

Nuswantara, B., "Analisa Penyaluran Kredit Mikro dan Kecil Pada Beberapa Lembaga Keuangan Mikro di Wilayah Jawa Tengah (Analysis of Micro and Small Credits on Microfinance Institutions in Central Java Region), National Conference and Call for Paper of Economic Faculty UNISBANK, (June 2012), Available at http://eprints.unisbank.ac.id/185/1/artikel-23.pdf, [Accessed on 15 October 2015].

Obamuyi, T. M., "An Exploratory Study of Loan Delinquency among Small and Medium Enterprises (SMEs) in Ondo State, Nigeria", Labour and Management in Development, (2009), vol 8, 1-9, Available at http://www.nla.gov.au/openpublish/index.php/lmd/article/viewFile/1352/1636, [Accessed on 18 October 2015].

Ogujiuba, K. K., Ohuche, F. K., and Adenuga, A. O., "Credit Availability to Small and Medium Scale Enterprises in Nigeria: Importance of New Capital Base for Banks-Background and Issues", Working Paper Series, (2004), Available at http:// econwpa.repec.org/eps/mac/papers/o411/0411002.pdf, [Accessed on $28^{\text {th }}$ November 2015].

Pratama, B.A. "Analisis Faktor-Faktor Yang Mempengaruhi Kebijakan Penyaluran Kredit Perbankan: Studi pada Bank Umum di Indonesia Periode Tahun 2005 - 2009", Unpublished Thesis of Program Pasca Sarjana, Diponegoro University, (Diponegoro University 2010).

Prawiranata, I. R. (2013). Sustainable microfinance in Indonesia: a sociocultural approach (Doctoral dissertation, Victoria University). 
Rigdon, E. E., \& Fergusson, C. E. The performance of the polychoric correlation coefficient and selected fitting functions in confirmatory factor analysis with ordinal data. Journal of Marketing Research, 28, (1991) 491-497.

Rosengard, J. K., \& Prasetyantoko, A. If the banks are doing so well, why can't I get a loan? Regulatory constraints to financial inclusion in Indonesia. Asian Economic Policy Review, (2011). 6 (2), 273-296.

Said, H., Bakri Badru, B., and Shahid M., "Confirmatory Factor Analysis for Testing Validity and Reliability Instrument in the Study of Education", Australian Journal of Basic and Applied Sciences: no 12, (2011), vol 5, 1098-1103.

Sastrosuwito, S., and Suzuki, Yasuhi., "The Determinant of Post-Crisis Indonesian Banking System Profitability", Economic and Finance Review, no 1, (2012), vol 11, 48-57.

Setyari, N. P. W. Evaluasi Dampak Kredit Mikro Terhadap Kesejahteraan Rumah Tangga di Indonesia: Analisa Data Panel. Jurnal Ekonomi Kuantitatif Terapan, no 2 (2012). Vol 5. $141-150$.

Shollapur, M.R., and Baligatti, Y.G., "Funds Management in Banks: A Cost-Benefit Perspective", International Business and Economics Research Journal, no 11, (2010), vol 9, $21-29$.

Steijvers, T., Voordeckers, W., and Vanhoof, K., "Collateral, Relationship Lending, and Family Firms", Small Business Economics, no 3, (2010), vol 34, $243-259$.

Sudirman, I. W., "Faktor-faktor Penghambat Peningkatan Loan to Deposit Ratio (LDR) Perbankan di Provinsi Bali”, Journal of Indonesian Economy and Business, (2003), p (nd).
Sutrisno, J., \& HS, S. L. (2006). Kajian Usaha Mikro Indonesia. Jurnal Pengkajian KUKM, 1(2). 13-25.

Tambunan, T. Financial Inclusion, Financial Education, and Financial Regulation: A Story from Indonesia. Working Paper Series in Cooperation With Asian Development Bank Institute (ADBI), Tokyo. (2015).

Tran, A.T., "Impact of Legal Environment on Bank Performance: An Empirical Study from a Developing Country", International Review of Business Research Papers, no 1, (2010), Vol 6., 299-318.

Uchida, H., Udell, G. F., and Watanabe, W., "Bank Size and Lending Relationships in Japan", Journal of the Japanese and International Economies, no 2, (2008), vol 22, 242267.

Vong, A.P.I., and Chan, H.S., "Determinants of Bank Profitability in Macao", Macau Monetary Research Bulletin, no 6, (2009), vol 12, 93113.

Wehinger, G., "SMEs and the credit crunch: Current Financing Difficulties, Policy Measures and a Review of Literature", OECD Journal: Financial Market Trends 2013, no 2, (2014), vol (nd), 115-148, Available at https://search.oecd.org/daf/ fin/financial-markets/SMEs-Credit-Crunch-Financing-Difficulties. pdf, [Accessed on 18 October 2015]. Woodford, Michael., "Financial Intermediation and Macroeconomic Analysis", Journal of Economic Perspectives, no 4, (2010), vol 24, $21-44$.

\section{BOOKs}

Riyadi, Slamet., "Banking Assets and Liability Management”, Edisi Ketiga, Fakultas Ekonomi Universitas Indonesia, (Fakultas Ekonomi UI 
2006).

Rivai, V., and Veithzal, P., "Credit Management Handbook: Teori, Konsep, Prosedur, dan Aplikasi Panduan Praktis Mahasiswa, Bankir, dan Nasabah", Edisi Pertama, (Published by PT. Raja Grafindo 2007).

Ghezzi, Simone., "Small-Scale Entrepreneurship in Modern Italy - an Ethnographic Analysis of Social Embededdedness in the Access to Capital and Credit", (INTECH Open Access Publisher, 2012).

Research Development Agency of North Sumatera Province., "The Role of Micro Credit (KUR) for People Economy Empowerment in North Sumatera", Research Development Agency of North Sumatera Province, (2011).

Burton, M., Nesiba, R., and Lombra, R. "An Introduction to Financial Markets and Institutions, (United
States, South-Western 2003).

Schumacker, R.E., and Lomax, R.G., "A Beginner's Guide to Structural Equation Modelling", $3^{\text {rd }}$ Edition, Taylor \& Francis Group in the United States of America, (Yaylor \& Francis 2010).

Waluyo, M., "Panduan dan Aplikasi Structural Equation Modelling (untuk aplikasi model dalam penelitian teknik industry, psikologi, sosial dan manajemen)", (PT. Indeks Jakarta 2011).

Ferdinand, A., "Structural Equation Modelling dalam Penelitian $\mathrm{Ma}$ najemen, Aplikasi Model-Model Rumit dalam Penelitian untuk Tesis Magister dan Disertasi, (Badan Penerbit Universitas Diponegoro 2005).

Wijanto, S., "Structural Equation Modelling dengan LISREL 8.8: Konsep and Tutorial", (Graha Ilmu, Yogyakarta 2008).

ANNEX 1 :

Qplot of Standardised Residual

Mahalanobis Test Using IBM SPSS Statistic 23

Residuals Statistics $^{\mathrm{a}}$

\begin{tabular}{|c|c|c|c|c|c|}
\hline & Minimum & Maximum & Mean & Std. Deviation & $\mathrm{N}$ \\
\hline Predicted Value & 11.9778 & 105.7646 & 61.5000 & 15.97271 & 122 \\
\hline Std. Predicted Value & -3.100 & 2.771 & .000 & 1.000 & 122 \\
\hline $\begin{array}{l}\text { Standard Error of Predicted } \\
\text { Value }\end{array}$ & $5 \cdot 537$ & 17.396 & 10.650 & 2.089 & 122 \\
\hline Adjusted Predicted Value & 13.8280 & 109.5475 & 61.6795 & 16.68525 & 122 \\
\hline Residual & -61.18603 & 82.26596 & .00000 & 31.54953 & 122 \\
\hline Std. Residual & -1.841 & 2.475 & .000 & .949 & 122 \\
\hline Stud. Residual & -2.018 & 2.666 & -.002 & 1.005 & 122 \\
\hline Deleted Residual & -73.54749 & $95 \cdot 44286$ & -.17954 & 35.41423 & 122 \\
\hline Stud. Deleted Residual & -2.047 & 2.744 & -.002 & 1.012 & 122 \\
\hline Mahal. Distance & 2.366 & 32.149 & 11.902 & 5.229 & 122 \\
\hline Cook’s Distance & .000 & .088 & .010 & .014 & 122 \\
\hline Centered Leverage Value & .020 & .266 & .098 & .043 & 122 \\
\hline
\end{tabular}


ANNEX 2 :

Measurement Equation and Statistical Goodness of Fit Indexes for the External-Specific Condition.

$\mathrm{X} 1=0.685^{*}$ EXTERNAL, Errorvar. $=0.357, \mathrm{R}^{2}=0.568$

$$
\text { Standerr (0.0743) (0.0573) }
$$

Z-values $9.222 \quad 6.232$

P-values $0.000 \quad 0.000$

$\mathrm{X} 2=0.727^{*}$ EXTERNAL, Errorvar. $=0.215, \mathrm{R}^{2}=0.711$

Standerr (0.0673) (0.0444)

Z-values $10.799 \quad 4.849$

P-values $0.000 \quad 0.000$

$\mathrm{X}_{3}=0.725^{*}$ EXTERNAL, Errorvar. $=0.278, \mathrm{R}^{2}=0.654$

Standerr (0.0712) (0.0505)

Z-values $10.183 \quad 5.505$

P-values $0.000 \quad 0.000$

$\mathrm{X} 4=0.611^{*}$ EXTERNAL, Errorvar. $=0.298, \mathrm{R}^{2}=0.556$

Standerr (0.0672) (0.0472)

Z-values $9.089 \quad 6.308$

P-values $0.000 \quad 0.000$

Table 1

Overall Statistical Goodness of Indexes for The External-Specific Condition

\begin{tabular}{lll}
\hline \multicolumn{1}{c}{ Model-Fit Criterion } & \multicolumn{1}{c}{ Estimate Results } & Rate of fit \\
\hline Chi-square & $\begin{array}{l}1.61(1.61<5.99) \text { or } \mathrm{P}=0.4480> \\
0.05)\end{array}$ & Good \\
Goodness-of-fit Index (GFI) & $0.993(0.993 \geq 0.90)$ & Good \\
Adjusted GFI (AGFI) & $0.966(0.966 \geq 0.90)$ & Good \\
Standardized RMR (SRMR) & $0.0142(0.0142<0.05)$ & Good \\
$\begin{array}{l}\text { Root-mean-square error of approximation } \\
\text { (RMSEA) }\end{array}$ & $0.0107(0.0107<0.08)$ & Good \\
Expected Cross-Validation Index (ECVI) & $0.148(0.148$ close 0.148 than to & Good \\
Normed fit index (NFI) & $0.204)$ & Good \\
$\begin{array}{l}\text { Tucker-Lewis index (TLI) / Non Normed } \\
\text { fit index (NNFI) }\end{array}$ & $0.993(0.993 \geq 0.95)$ & Good \\
Relative fit index (RFI) & $1.000(1.000 \geq 0.95)$ & Good \\
Incremental fit index (IFI) & $0.979(0.979 \geq 0.95)$ & Good \\
Comparative fit index (CFI) & $1.000(1.000 \geq 0.95)$ & Good \\
Critical N (CN) & $1.000(1.000 \geq 0.95)$ & Good \\
\hline
\end{tabular}




\section{ANNEX 3 :}

Measurement Equations and Statistical Goodness of Fit Indexes for the Internal-Specific Condition.

Y1.1 = 0.627*INTERNAL, Errorvar. $=0.367, \mathrm{R}^{2}=0.517$
Standerr (0.0730)
(0.0573)
Z-values 8.587
6.400
P-values 0.000
0.000

Y1.2 $=0.613^{*}$ INTERNAL, Errorvar. $=0.186, \mathrm{R}^{2}=0.669$

Standerr (0.0599)

(0.0364)

Z-values 10.229

5.123

P-values 0.000

0.000

Y1.3 = $0.663^{*}$ INTERNAL, Errorvar. $=0.225, \mathrm{R}^{2}=0.661$

Standerr (0.0653) (0.0432)

Z-values $10.151 \quad 5.207$

P-values $0.000 \quad 0.000$

Y1.4 $=0.677^{*}$ INTERNAL, Errorvar. $=0.368, \mathrm{R}^{2}=0.555$

Standerr (0.0752) (0.0596)

Z-values $9.001 \quad 6.166$

P-values $0.000 \quad 0.000$

Table 2

Overall Statistical Goodness of Indexes for the Internal-Specific Condition

Model-Fit Criterion

Chi-square

Goodness-of-fit Index (GFI)

Adjusted GFI (AGFI)

Standardized RMR (SRMR)

Root-mean-square error of approximation (RMSEA)

Expected Cross-Validation Index (ECVI)

Normed fit index (NFI)

Tucker-Lewis index (TLI) / Non Normed fit index (NNFI)

Relative fit index (RFI)

Incremental fit index (IFI)

Comparative fit index (CFI)

Critical N (CN)
Estimate Results

Rate of fit

$0.910(0.910<5.99)$ or $\mathrm{P}=0.63432$

$>0.05$ )

Good

$0.996(0.996 \geq 0.90)$

Good

$0.981(0.981 \geq 0.90)$

Good

$0.0109(0.0109<0.05)$

Good

$0.00758(0.00758<0.08)$

Good

0.148 ( 0.148 is minimum point

than to 0.188 )

Good

$0.996(0.993 \geq 0.95)$

Good

$1.000(1.000 \geq 0.95)$

Good

$0.987(0.987 \geq 0.95)$

Good

$1.000(1.000 \geq 0.95)$

Good

$1.000(1.000 \geq 0.95)$

Good

$1225.228(1225.228 \geq 200)$

Good 


\section{ANNEX 4 :}

Measurement Equations and Statistical Goodness of Fit Indexes the Loan-Officer Judgment(s) and Decision(s).

Y2.1 $=0.626^{*}$ OFFICER, Errorvar. $=0.290, \mathrm{R}^{2}=0.575$

$\begin{array}{lll}\text { Standerr } & (0.0691) & (0.0508) \\ \text { Z-values } & 9.057 & 5.706 \\ \text { P-values } & 0.000 & 0.000\end{array}$

Y2.2 $=0.632^{*}$ OFFICER, Errorvar. $=0.373, \mathrm{R}^{2}=0.517$

Standerr (0.0748) (0.0606)

Z-values $8.447 \quad 6.152$

P-values $0.000 \quad 0.000$

Y2.3 $=0.751^{*}$ OFFICER, Errorvar. $=0.340, \mathrm{R}^{2}=0.623$

$\begin{array}{lll}\text { Standerr }(0.0785) & (0.0650) \\ \text { Z-values } & 9.559 & 5.235 \\ \text { P-values } & 0.000 & 0.000\end{array}$

Y2.4 $=0.687^{*}$ OFFICER, Errorvar. $=0.376, \mathrm{R}^{2}=0.556$

Standerr (0.0775) (0.0642)

Z-values $8.866 \quad 5.860$

P-values $0.000 \quad 0.000$

Table 3

Overall Statistical Goodness of Indexes for the Loan-Officer Judgment and Decision(s)

\begin{tabular}{lll}
\hline \multicolumn{1}{c}{ Model-Fit Criterion } & \multicolumn{1}{c}{ Estimate Results } & Rate of fit \\
\hline Chi-square & $\begin{array}{l}0.482(0.482<5.99) \text { or } \mathrm{P}=0.7868 \\
\text { o.05 })\end{array}$ & Good \\
Goodness-of-fit Index (GFI) & $0.998(0.996 \geq 0.90)$ & Good \\
Adjusted GFI (AGFI) & $0.990(0.981 \geq 0.90)$ & Good \\
Standardized RMR (SRMR) & $0.00868(0.00868<0.05)$ & Good \\
$\begin{array}{l}\text { Root-mean-square error of approximation } \\
\text { (RMSEA) }\end{array}$ & $0.00693(0.00693<0.08)$ & Good \\
Expected Cross-Validation Index (ECVI) & $0.148(0.148$ is the minimum point & Good \\
than to 0.174$)$ & Good \\
$\begin{array}{l}\text { Tucker-Lewis index (TLI) / Non Normed } \\
\text { fit index (NNFI) }\end{array}$ & $0.997(0.997 \geq 0.95)$ & Good \\
Relative fit index (RFI) & $1.000(1.000 \geq 0.95)$ & Good \\
Incremental fit index (IFI) & $0.992(0.992 \geq 0.95)$ & Good \\
Comparative fit index (CFI) & $1.000(1.000 \geq 0.95)$ & Good \\
Critical N (CN) & $1.000(1.000 \geq 0.95)$ & $2313.329(2313.329 \geq 200)$ \\
\hline
\end{tabular}


ANNEX 4 :

T-value of the Loading, Residual and Coefficient Parameter (Full SEM Model)

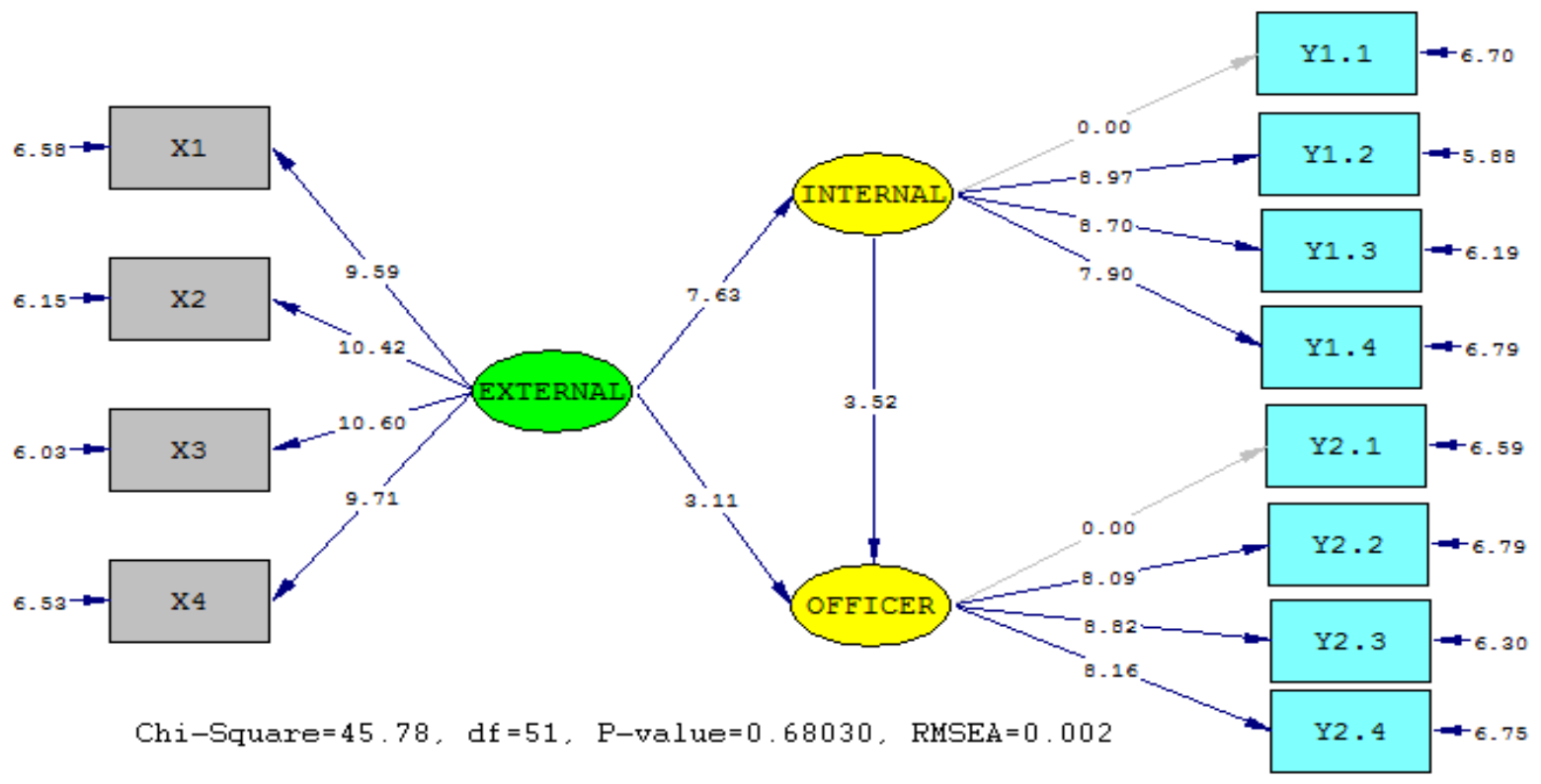

COVARIANCE MATRIX

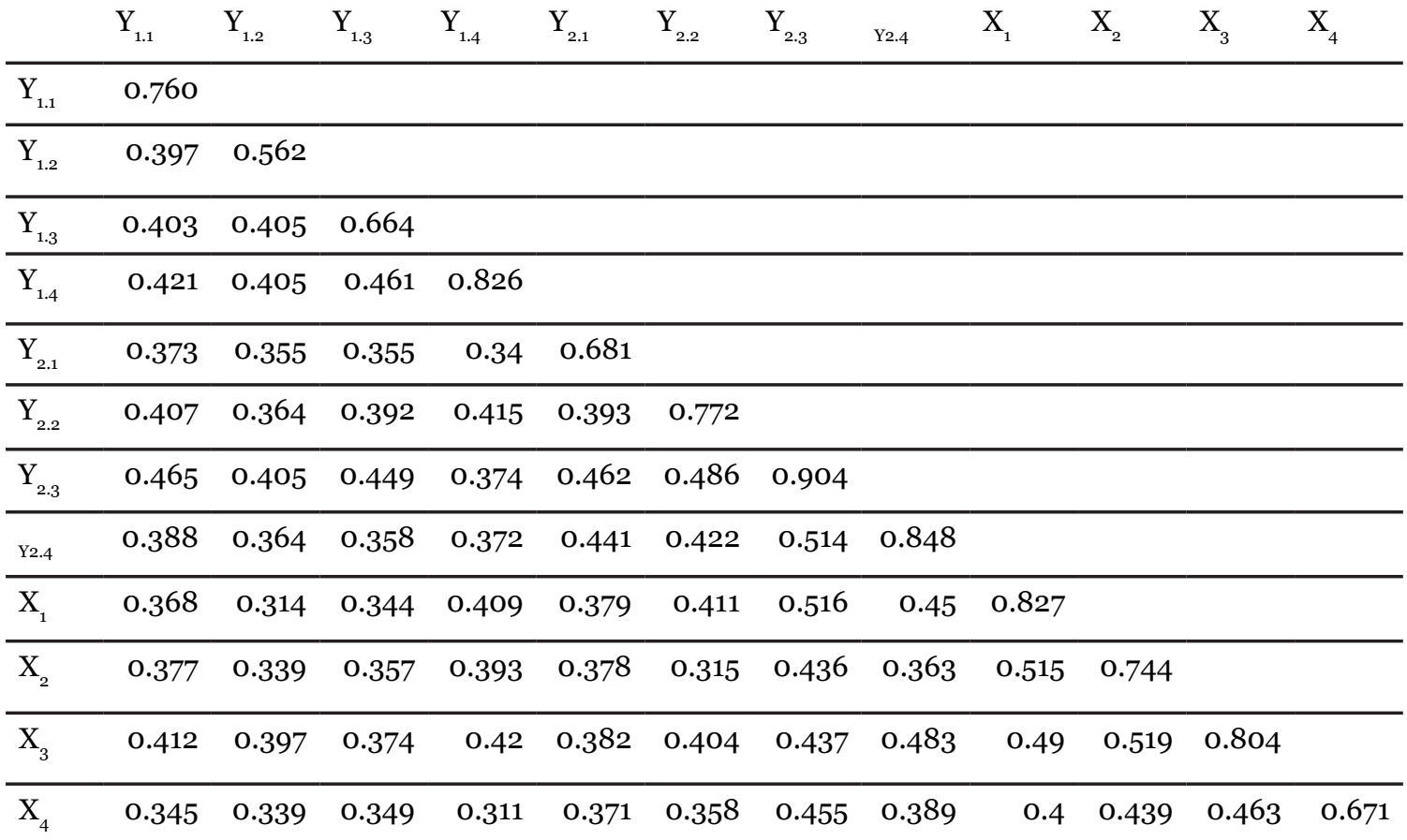

COVARIANCE MATRIX OF LATENT VARIABLE

\begin{tabular}{|l|r|r|r|}
\hline & \multicolumn{1}{|l|}{ Internal } & \multicolumn{1}{l|}{ Officer } & External \\
\hline Internal & 1.0000 & & \\
\hline Officer & 0.8900 & 1.0000 & \\
\hline External & 0.8220 & 0.8750 & 1.0000 \\
\hline
\end{tabular}

